\title{
Influence of pinching on growth and yield of bottle gourd (Lagenaria siceraria)
}

\author{
Muhammad Naafe ${ }^{1 *}$, Ghulam Nabi ${ }^{1}$, Muhammad Irshad ${ }^{1}$, Muhammad \\ Noman Khan ${ }^{1}$, Shamsher Ali ${ }^{2}$ and Raheel Hayat ${ }^{3}$ \\ 1. Department of Horticulture, The University of Agriculture, Peshawar, Pakistan \\ 2. Department of Soil \& Environmental Sciences, The University of Agriculture, Peshawar, Pakistan \\ 3. Department of plant protection, The University of Agriculture, Peshawar, Pakistan \\ *Corresponding author's email: Muhammadnaafi11@gmail.com \\ Citation
}

Muhammad Naafe, Ghulam Nabi, Muhammad Irshad, Muhammad Noman Khan, Shamsher Ali and Raheel Hayat. Influence of pinching on growth and yield of bottle gourd (Lagenaria siceraria). Pure and Applied Biology. Vol. 11, Issue 4, pp891-901. http://dx.doi.org/10.19045/bspab.2022.110091

\begin{tabular}{llll}
\hline \hline Received: $12 / 11 / 2021$ & Revised: 13/01/2022 & Accepted: 31/01/2022 & Online First: 08/02/2022 \\
\hline
\end{tabular}

\section{Abstract}

The research study "Influence of pinching on growth and yield of bottle gourd (Lagenaria siceraria L)" was conducted during April-October 2019 at Palatoo Research Farm, Amir Muhammad Khan Campus Mardan. The study was conducted out according to RCBD, split plot arrangement and then three times replicated. Bottle gourd varieties (Lauki, Pusa samridhi and $\mathrm{CO} 1$ hybrid) were assigned to main plots while pinching levels i.e. $1^{\text {st }}$ node, $2^{\text {nd }}$ node and $3^{\text {rd }}$ node stage and No pinching (control) were assigned to sub plots. The results of current study reveal that Pinching treatment significantly influenced yield and growth parameters of bottle gourd. According to the stages of pinching, plants pinched at $3^{\text {rd }}$ (three) node stage produced more lateral branches. (3.55 plant $\left.^{-1}\right)$, early male flower appearance ( 36.33 days), early female flower appearance (41.33), lowest vine length $(2.36 \mathrm{~m})$, more female flowers vine ${ }^{-1}$ (9.11), highest fruit set percentage $(73.88 \%)$, lengthy fruit $(24.33 \mathrm{~cm})$, more number of fruits. plant $^{-1}$ (7.78), fruit weight. (419.11 g), yield. plant ${ }^{-1}(5.44 \mathrm{~kg})$ and yield. ha ${ }^{-1}(12.92 \mathrm{t})$, whereas more male flower vine ${ }^{-1}$ (70.11) were recorded in plants that were not pinched. Furthermore, among the tested varieties CO1 hybrid variety produced more lateral branches plant $^{-1}(3.28)$, early male flower appearance (35.50 days), early female flower appearance (40.25 days), lowest vine length $(2.39 \mathrm{~m})$, highest fruit set percentage $(75.75 \%)$, maximum fruit weight (418 $\mathrm{g})$, highest total yield plant ${ }^{-1}(5.04 \mathrm{~kg})$ and total yield ha ${ }^{-1}(12.71 \mathrm{t})$ while more male flowers vine $^{-1}(68)$, more female flowers vine ${ }^{-1}(9.16)$ and more number of fruits plant ${ }^{-1}$ (7.75) were noted for Lauki. Furthermore, lengthy fruit $(24.45 \mathrm{~cm})$ was recorded for variety Pusa samridhi. From the above results, it is concluded that pinching treatment at $3^{\text {rd }}$ node stage and bottle gourd varieties particularly Lauki and $\mathrm{CO} 1$ hybrid is better for the overall growth and yield.

Keywords; Female flower; Length; Male flowers; Pinching; Yield

\section{Introduction}

Bottle gourd (Lagenaria siceraria L.) is one of a popular cucurbitaceous vegetable mostly cultivated in warmer regions of the world. In Khyber Pakhtunkhwa it is known as Kadu, and relate to the genus Lagenaria.
Lagenaria species are the most famous in cucurbitaceous family. In older literature it is referred as Lagenaria leucantha means white colour flower gourd), but it is now generally agreed that Lagenaria siceraria is the correct name. It is originated from India. 
Previous Indian literatures reported its cultivation 2000 B.C [1].

Bottle gourd is adapted to semi-arid conditions and needs 500-600 mm welldistributed rainfall annually. The optimum temperature for germination is $20-25^{\circ} \mathrm{C}$; however, it is decreases below $15^{\circ} \mathrm{C}$ and above $35^{\circ} \mathrm{C}$. Bottle gourd can now tolerate low temperature, its temperature below $10^{\circ} \mathrm{C}$ drops, when flowering is reduced [2]. Bottle gourd is one of the excellent and gifted by nature fruit vegetable to human beings because it consists of all the major and micronutrients that are required to maintain good health and quality of human life [3].

Bottle gourd is much important for its medicinal and nutritional properties. In 100 $\mathrm{g}$ of fruit may contain protein $(0.2 \mathrm{~g})$, carbohydrate $(2.5 \mathrm{~g})$ and traces of minerals like calcium (20mg), iron $(0.7 \mathrm{mg})$ and phosphorus (10mg) [4].

Due to its andromonoecious nature, it is a cross pollinated crop and as a results contain wide genetic variability for maturity, fruit characters and yield [5]. It produces more female flowers during spring-summer, under high temperature and long days [6].

Irrigation to the crop depends upon the temperature, wind velocity, soil type, site, relative humidity, and orientation. The crop sown in spring season i.e., Feb..and Mar. Needs $1^{\text {stirrigation } 2}$ days after seed sowing, and later on at with 7 or 8 day intervals, while during summer having hot and dry conditions, the interval can be shortening. The early $1^{\text {st }}$ watering is practiced one or two days before the seed sowing and the onward after 4 or 5 days' interval. Excessive watering also effects the crop growth in fruit set stage [7].

The use of organic manures and fertilizers also depends on season, soil type, and climatic conditions of the area. Organic manuring at thirty tonnes per hectare is need to be applied at the time of field preparation, while in Pakistan (NPK @ 164,114 and $164 \mathrm{~kg} \mathrm{ha}^{-1}$ is beneficial for good production of bottle gourd crop [8].
The optimum growing condition for Bottle gourd is warm season, but it is poorly tolerant to frost condition. The best temperature for seed germination is $25-30^{\circ}$ [9]. This crop can be grown in vide ranges of soils types, however, sandy loams having well drainage are considered better options for its cultivation. For the favourable plant growth, the best $\mathrm{pH}$ is 6 to 7 . The growth of bottle gourd noticed bets under light intensity up to 50\% PAR [10].

In bottle gourd, flowering starts after 40-50 days of sowing, but influenced by cultivar and environmental conditions also. In general, staminate flowers appeared first than the pistillate in the axis of nodes on main and secondary branches. The node of first female flower is considered as an indicator of earliness [11]. In Pakistan Bottle gourd was cultivated on 5492 ha land and produced is 55640 tonnes of fruits, where as in Khyber Pakhtunkhwa the area cultivated of this crop was 530 ha and production was 4600 tonnes [12].

Because of its growing and fruiting nature, it is mostly grown as garden vegetable in Khyber Pakhtunkhwa. It is cross pollinated crop, and the fruiting depends on sex ratio (male and female flowers on vine). Previous work on cucurbits demonstrated that male flowers occurs mostly on main vine (branch), whereas, female flowers occurs on secondary branches [13].

Due to high fertilization and irrigation, the main vine grows rapidly resulting less number of secondary branches, which ultimately results less number of female flowers production leading to fewer yield. Pinching is a kind of pruning which encourages tertiary sprouts in the plant. In this method the tips of main branch are cut down when the plant is very small, this operation encourages secondary and tertiary branches and improve the balance between vegetative and reproductive growth to enhance production [13]. Due to pinching practice the plant is injured, becomes susceptible to environmental stress, diseases and fungal attacks [14]. 
This method is easy and economical as compared to other approaches like PGRs and chemical applications to balance the vegetative and reproductive growth. Previously pinching has been proved effective to encourage secondary branches, female flower production and fruit yield in butternut [15], Tomato [16] and cucumber [17]. The research was conducted to investigate the influence pinching practice on theyield and growth. of. bottle gourd.

\section{Objectives of the study}

1. To identify the best variety of bottle gourd

2. To identify the proper stage of pinching

3. To validate the interactive effect of variety and pinching stage

Main plot (Varieties) Sub Plot (Pinching)

$\mathrm{V} 1=$ Leuki (Local Variety) $\mathrm{P} 1=$ No pinching

V2= Pusa samridhi $\quad \mathrm{P} 2=1$ st node. stage

$\mathrm{V} 3=\mathrm{CO} 1$ hybrid $\quad \mathrm{P} 3=2$ nd node. stage

P4= 3rd node. stage

\section{Materials and Methods}

The research study "Influence of pinching on growth and yield of bottle gourd (Lagenaria. siceraria)" was carried at Palatoo Research. Farm AMK Campus Mardan, The University of Agriculture Peshawar during April-October 2019. The main objective of this trial was to know the effects of pinching treatment on growth and yield of bottle gourd.

\section{Land. preparation}

The selected land for the trial was thoroughly ploughed and levelled, seeds were sown on ridges Palatto Plant and Row to Row distance of 2 and $1.5 \mathrm{~m}$ were maintained respectively. In general, farmyard manure at 30 tonnes $\mathrm{ha}^{-1}$ and NPK at 164,114 and $164 \mathrm{~kg} \mathrm{ha}^{-1}$ were applied, suggested by Jan et al. [8]. All potash, phosphorous, and half. of nitrogen was added during sowing time, whereas during earthling up the remaining half $\mathrm{N}$ was applied.

\section{Seed source and cultural practices}

Seeds of local and hybrid varieties of bottle gourd were purchased from a reliable. retailer shop in Swabi. Twelve (12) treatment. combinations. were made, Four seeds/treatment. were sown with a total of 48 seeds (12 treatments combinations $\mathrm{x} 4$ seeds) were sown in each replication.

Seeds were sown on $25^{\text {th }}$ April and pinching was done at $1^{\text {st }}$ node stage, $2^{\text {nd }}$ node stage and $3^{\text {rd }}$ node stage. $1^{\text {st }}$ node stage pinching was practiced at 4 to 5 days after germination, $2^{\text {nd }}$ node stage pinching at 7 to 8 days after germination while $3^{\text {rd }}$ node stage at 10 days after germination.

\section{Experimental practical}

Bottle gourd varieties (Factor A) were placed in main plot, whereas, pinching levels. (Factor B) were kept in sub plots. In a single replication, there were 12 treatments combination and each combinations was repeated three times to minimize the experimental error and minimize the effect of any biases in the results.

\section{Statistical analysis}

The experiment was repeated three times No pinching was used as a control treatment at every step of the analysis. Two-way analysis of variance was practiced by using Statistix 8.1 for all statistical analysis, and the variation between treatment means were evaluated by using Least Significant. Difference test at $(\mathrm{P}<0.05)$ and $(\mathrm{P}<0.01)$ [18].

\section{Studied parameters}

Number of lateral. branches. plant ${ }^{-1}$

Number of lateral branches of each subplot of each repetition were counted and their average was recorded.

\section{Days to $1^{\text {st }}$ female flower appearance}

Number of days were counted from the date of sowing to the $1^{\text {st }}$ female. flower appearance in all treatment and average data was computed.

\section{Days to $1^{\text {st }}$ male flower appearance}

Days were counted from the sowing date to the appearance of $1^{\text {st }}$ male flower in all treatment of each repetition and average data was calculated.

\section{Length of vine (m)}

Length of vines were measured with a measuring tape and average data was 
recorded for all treatments of each repetition.

\section{Number of male flowers vine vi $^{-1}$}

Number of male flowers vine ${ }^{-1}$ of each subplot of each repetition were identified, counted and average was calculated.

\section{Number of female flowers vine ${ }^{-1}$}

Number of female flowers vine ${ }^{-1}$ of each subplot of each repetition were identified, counted and average was calculated.

Number of fruits vine $\mathrm{v}^{-1}$

Number of fruits vine ${ }^{-1}$ of each subplot of each repetition were counted and average was computed and recorded.

\section{Fruit setpercentage (\%age)}

Number of fruit set plant ${ }^{-1}$ and number of female flowers plant $^{-1}$ of each subplot of each repetition were counted and average was recorded and fruit set percentage were determined from the following equations.

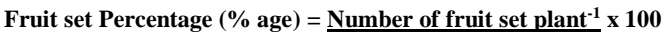

\section{Length of fruit (cm)} Number of female flowers plant $^{-1}$

Length of fruit $(\mathrm{cm})$ of each subplot of each repetition were measured, and average was computed.

\section{Number of fruits vine ${ }^{-1}$}

Total number of fruits vine ${ }^{-1}$ were counted in selected plants and average data was recorded.

\section{Yield plant ${ }^{-1}(\mathbf{K g})$}

The Total mean yield plant ${ }^{-1}$ of each subplot of each repetition were determined with the help of weighting machine or by using Digital balance and average data was calculated and recorded for all the studied treatments.

\section{Total yield ha-1 (Tonns)}

Total yield $\mathrm{ha}^{-1}$ of each subplot of each repetition were determined from the yield plot $^{-1}$ and average data was recorded for all the selected treatments. Calculation was done with the help of the following formula

$$
\text { Yield ha } \mathrm{h}^{-1}=\frac{\text { Sum of all picking weight }}{\text { Plot area }\left(\mathrm{m}^{2}\right) \underline{x} 1000} 10000
$$

\section{Results and Discussion}

The current study entitled "Influence of pinching on growth and yield of Bottle gourd " was carried out at Palatto Research
Farms, AMK Campus Mardan during 2019 growing season. All the data obtained on various parameters were statistically analysed. Analysis of variance and mean tables were calculated in order to interpret the results regarding number of lateral branches, early male flower appearance, early female flower appearance, length of vine, number of male and female flowers vine $^{-1}$, fruit set vine ${ }^{-1}$, length of fruit, fruits quantity plant $^{-1}$, fruit weight and fruit yield $\mathrm{ha}^{-1}$.

\section{Number of lateral branches plant $\mathbf{t}^{-1}$}

In (Table 1), the mean values for number of lateral branches plant ${ }^{-1}$ is calculated. As evident from the table that pinching practice and varieties significantly influence number of lateral branches in Bottle gourd, while their interactive effect was non-significant.

Among the tested bottle gourd varieties, maximum number of lateral branches plant ${ }^{-}$ ${ }^{1}$ (3.28) was found in CO1 hybrid followed by Pusa samridhi (3.01), while minimum number of lateral branches plant ${ }^{-1}$ (2.59) was found in Lauki.

In case of pinching treatment, more lateral branches plant ${ }^{-1}$ (3.55) were found in plants that were pinched at $3^{\text {rd }}$ node stage followed by 2 nd node (3.49) stage, while lowest lateral branches (2.01) were noted in plants that were not pinched.

With apical bud removal the cytokinin stimulates, which promotes lateral branches [14]. Eve et al. [15] demonstrated that due to pinching plants become physiologically active, thus the concentration of photosynthate divert to lower parts of the plant that suppresses growth of the main stem and encourages production of lateral branches. According to Pimpini and Gianquinto [19] pinching diverts auxins concentration from tips to lower parts of the plant, making plants physiologically active, thus increase in lateral branches take place. Previously, the more lateral branches due to pinching practice has been documented in other vegetable crop species including Fenugreek [20], Tomato [16] and cucumber [17]. 
Days taken to $1^{\text {st }}$ male flower appearance In (Table 1), the mean values for days taken to first male flower appearance is calculated. As evident from the ANOVA table that pinching practice and varieties significantly influence days to $1^{\text {st }}$ male flower appearance in Bottle gourd, while their interactive effect was non-significant. Among tested Bottle gourd varieties, CO1 hybrid showed early (35.50 days) $1^{\text {st }}$ male flower appearance followed by Lauki (36.75 days), while late male flowering (38.54 days) was recorded in Pusa samridhi.

In case of pinching, plants pinched at $3^{\text {rd }}$ node stage give earlier (36.33 days) $1^{\text {st }}$ male flower appearance, followed by (36.67 days) pinched at $2^{\text {nd }}$ node, while late male flowering (37.50 days) were observed in plants pinched at $1^{\text {st }}$ node stage.

The earlier appearance of male flowers in pinched plants might be due the modification of auxin andcytokinins concentration in plant. Patel et al. [13] demonstrated that due to pinching more cytokinins accumulates in lower parts of plants which in turn promotes lateral branches. Moreover, pinching has been documented to balance carbon nitrogen ratio in plants that in turns stimulates flowering in plants [17]. Similar to our study pinching treatment remained effective for early flowering in different vegetable crops including, Fenugreek [21], Butternut [15] and Cucumber [22].

\section{Days taken to first female flower appearance}

In (Table 1), the mean values for days taken to first female flower appearance is calculated. As evident from the ANOVA table that pinching practice and varieties significantly influence days to $1^{\text {st }}$ female flower appearance in Bottle gourd, while their interactive effect was non-significant. Among tested Bottle gourd varieties, early $1^{\text {st }}$ female flower appearance (40.25 days) were recorded in $\mathrm{CO} 1$ hybrid followed by Lauki (41.58 days), while late $1^{\text {st }}$ female flower appearance (43.75 days) was recorded for Pusa samridhi.
In case of pinching practice, early $1^{\text {st }}$ female flower appearance (41.33) were recorded in plants pinched at $3^{\text {rd }}$ node stage followed by $2^{\text {nd }}$ node stage (41.56 days), while late female flowering (42.33 days) were recorded in plants that were not pinched.

The early appearance of female flowers might be due to change in auxin and cytokinins levels, pinching enhances cytokininns levels, which in turn promotes lateral branches that are capable to produce early female flowering [13]. Similar to our study, pinching treatmenthas been documented effective for earliness in female flowering in different vegetable crops including Fenugreek [21], Butternut [15] and Cucumber [22].

\section{Length of vine (m)}

In (Table 1), the mean values for length of vine is calculated. As evident from the ANOVA table that pinching practice and varieties significantly influence length of vines in Bottle gourd, while their interaction was found non-significant.

Among tested Bottle gourd varieties, maximum vine length $(2.47 \mathrm{~m})$ was recorded for variety Pusa samridhi followed by Lauki $(2.44 \mathrm{~m})$, while minimum vine length $(2.39 \mathrm{~m})$ were noted in CO1 hybrid. In case of pinching treatment, highest vine length $(2.48 \mathrm{~m})$ was noted in plants that were not pinched, followed by pinching at $1^{\text {st }}$ node stage $(2.45 \mathrm{~m})$, while lowest vine length $(2.36 \mathrm{~m})$ was recorded in plants pinched at $3^{\text {rd }}$ node stage.

The decrease in vine length might be due to decrease in auxin concentration in apical portion of plants, thus vine growth decreased. As a result of pinching, plants physiologically became active and diverts the concentration of photosynthate to lower parts of the plant thus minimising the vine length [14]. Patel et al. [13] demonstrated that due removal of apical portion the growth of main stem is suppressed. Similar to our study, reduce vine length has been observed previously as a result of pinching practice in many vegetable crops species including Cucumber [23], Butternut [15] and Fenugreek [20]. 
Number of male flowersvine ${ }^{-1}$

In (Table 1), the mean values for number of male flowers vine $^{-1}$ is calculated. As evident from the ANOVA table that pinching practice and varieties significantly influence number of male flowers vine ${ }^{-1}$ in Bottle gourd, while their interaction was found non-significant.

Among tested Bottle gourd varieties, more male flowers vine ${ }^{-1}$ (68.08) were recorded in Lauki followed by CO1 hybrid (64.33), while lowest number of male flowers vine ${ }^{1}$ (64.08) were recorded in Pusa samridhi.

In case of pinching practice, plants that were not pinched produced more male flowers vine ${ }^{-1}$ (70.11), followed by plants pinched at $1^{\text {st }}$ node (66.55), while lowest male flowers vine ${ }^{-1}$ (61.89) were found in plants pinched at $3^{\text {rd }}$ node stage.

Lateral branches are good producers of female flowers [14], due to pinching practice number of lateral branches increases that in turn promotes female flower production, while male flowers reduce in number [13]. The decrease in male flower production in bottle gourd may be associated with $\mathrm{C}: \mathrm{N}$ balance and endogenous levels of hormones. Similar to our findings, less male flowers production has been documented due to pinching practice in different vegetables plant species including Cucumber [24], Fenugreek [25] and Butternut [15].

Table 1. Number of lateral branches, Days to $1^{\text {st }}$ male flower appearance, Days to $1^{\text {st }}$ female flower appearance, Vine length(m), Number of male flowers vine ${ }^{-1}$, Number of female flowers vine ${ }^{-1}$

\begin{tabular}{|c|c|c|c|c|c|c|}
\hline Factor Levels & $\begin{array}{c}\text { Number } \\
\text { of } \\
\text { Lateral } \\
\text { branches }\end{array}$ & $\begin{array}{l}\text { Days to } 1^{\text {st }} \\
\text { male flower } \\
\text { appearance }\end{array}$ & $\begin{array}{l}\text { Days to } 1^{\text {st }} \\
\text { female } \\
\text { flower } \\
\text { appearance }\end{array}$ & $\begin{array}{c}\text { Vine } \\
\text { length } \\
\text { (m) }\end{array}$ & $\begin{array}{c}\text { Number } \\
\text { of males } \\
\text { flowers } \\
\text { vine }^{-1}\end{array}$ & $\begin{array}{c}\text { Number } \\
\text { of } \\
\text { females } \\
\text { flowers } \\
\text { vine }^{-1}\end{array}$ \\
\hline \multicolumn{7}{|c|}{ Pinching stages } \\
\hline No Pinching & $2.01 \mathrm{C}$ & $37.22 \mathrm{a}$ & $42.33 \mathrm{a}$ & $2.48 \mathrm{a}$ & $70.11 \mathrm{a}$ & $7.11 \mathrm{~b}$ \\
\hline $1^{\text {st }}$ node & $2.67 \mathrm{~B}$ & $37.50 \mathrm{a}$ & $42.22 \mathrm{a}$ & $2.45 \mathrm{ab}$ & $66.55 \mathrm{ab}$ & $8.00 \mathrm{ab}$ \\
\hline $2^{\text {nd }}$ node & $3.49 \mathrm{~A}$ & $36.67 \mathrm{ab}$ & $41.56 \mathrm{ab}$ & $2.41 \mathrm{bc}$ & $63.44 \mathrm{~b}$ & $9.11 \mathrm{a}$ \\
\hline $3^{\text {rd }}$ node & $3.55 \mathrm{~A}$ & $36.33 \mathrm{~b}$ & $41.33 \mathrm{a}$ & $2.36 \mathrm{c}$ & $61.89 \mathrm{~b}$ & $9.11 \mathrm{a}$ \\
\hline $\operatorname{LSD}(P \leq 0.05)$ & 0.45 & 2.11 & 0.82 & 0.072 & 5.96 & 1.28 \\
\hline \multicolumn{7}{|c|}{ Varieties } \\
\hline Lauki & $3.01 \mathrm{ab}$ & $36.75 \mathrm{AB}$ & $41.58 \mathrm{ab}$ & $2.41 \mathrm{~b}$ & $68.08 \mathrm{a}$ & $9.16 \mathrm{a}$ \\
\hline Pusa Samridhi & $2.59 \mathrm{~b}$ & $38.54 \mathrm{~A}$ & $43.75 \mathrm{a}$ & $2.47 \mathrm{a}$ & $64.08 \mathrm{~b}$ & $7.41 \mathrm{~b}$ \\
\hline C01 Hybrid & $3.28 \mathrm{a}$ & $35.50 \mathrm{~B}$ & $40.25 \mathrm{~b}$ & $2.39 \mathrm{~b}$ & $64.33 \mathrm{~b}$ & $8.41 \mathrm{ab}$ \\
\hline $\mathbf{L S D}(\mathbf{P} \leq \mathbf{0 . 0 5})$ & 0.4874 & 0.8335 & 2.25 & 0.037 & 2.85 & 1.26 \\
\hline
\end{tabular}

Number of female flowers vine - $^{-1}$

In (Table 1), the mean values for number of female flowers vine $^{-1}$ is calculated. As evident from the ANOVA table that pinching practice and varieties significantly influence number of female flowers vine ${ }^{-1}$ in Bottle gourd while their interaction was found non-significant.

Among tested Bottle gourd varieties, more female flowers vine $^{-1}$ was observed in Lauki (9.16) followed by CO1 hybrid (8.41), while lowest female flowers vine ${ }^{-1}$ (7.41) were noted in Pusa samridhi.
In case of pinching practice, more female flowers $v^{-1} e^{-1}(9.11)$ were noted in plants pinched at $3^{\text {rd }}$ node stage followed by pinching at $2^{\text {nd }}$ node (9.11), while lowest female flowers vine ${ }^{-1}(7.11)$ were recorded in plants that were not pinched.

Due to pinching practice, translocation of stored food towards the lateral branches increases, this in turn increases the metabolic activities of the plant [26], moreover, lateral branches have more carbohydrates as compared to main stem, and therefore they bear more female 
flowers Patel. Patel et al. [13] demonstrated that, due to pinching treatment endogenous levels of hormones accelerates that in turn promotes lateral branches as well as female flowers production. Similar to our findings, more number of female flowers have been recorded in Bottle guard [14] and in Cucumber [17] pinched at $3^{\text {rd }}$ node stage.

\section{Fruit set (\% age)}

In (Table 2), the mean values for fruit set percentage is calculated. As evident from the ANOVA table that pinching practice and varieties significantly influence and their interaction were found non-significant in Bottle gourd.

Among the tested Bottle gourd varieties, the highest fruit set percentage $(75.33 \%)$ were recorded for $\mathrm{CO} 1$ hybrid followed by pusa samridhi $(72.00 \%)$, while lowest fruit set percentage $(65.30 \%)$ were observed for Lauki.

In case of pinching practice highest fruit set percentage $(74.46 \%)$ were recorded in plants pinched that are not pinched followed by pinching at $3^{\text {rd }}$ node $(70.00 \%)$, while lowest fruit set percentage $(66.64 \%)$ were recorded in plants that pinched at $2^{\text {nd }}$ node.

Pinching practice did not influence fruit set percentage, however due to the endogenous hormones levels promotes lateral branches, and more female flowers [13]. Anand et al. [14] demonstrated that lateral branches are the good producers off male flowers, and the vine having more female flowers will bear more fruits. Similar to our results that pinching practice did not influence fruit set percentage have been reported in a number of plant species including, Fenugreek [25] and Tomato [16] and Cucumber [22].

\section{Length of fruit $(\mathbf{c m})$}

In (Table 2), the mean values for length of fruit is calculated. As evident from the ANOVA table that pinching practice and varieties significantly influence length of fruit in Bottle gourd while their interaction was found non-significant.

Among the different Bottle gourd varieties, highest fruit length $(24.45 \mathrm{~cm})$ were recorded in variety Pusa samridhi followed by Lauki $(23.0 \mathrm{~cm})$, while lowest fruit length $(22.25 \mathrm{~cm})$ were recorded for $\mathrm{CO} 1$ hybrid.

In case of Pinching practice, highest fruit length $(24.33 \mathrm{~cm})$ were recorded in plants pinched at $3^{\text {rd }}$ node stage followed by pinching at $2^{\text {nd }}$ node $(23.94 \mathrm{~cm})$, while lowest average fruit length $(21.83 \mathrm{~cm})$ were recorded for plants that were not pinched.

As evident from the ANOVA table that pinching practice and varieties significantly influence. Due to pinching treatment the photsynthate and endogenous hormones diverts towards lateral branches which in turn enhances growth processes [13]. Due to pinching concentration of auxin reduces while cytokinine concentration increases, which helps to balance the plant carbon nitrogen ratio, resulting accumulation of more photosynthate, thus pinching may increases fruit length [14]. Similar to our findings of this study lengthy fruits were noted in Bottle gourd [13] and in Cucumber [22] after pinching treatment.

\section{Number of fruits vine ${ }^{-1}$}

In (Table 2), the mean values for number of fruits vine ${ }^{-1}$ is calculated. As evident from the ANOVA table that pinching practice and varieties significantly influence number of fruits vine ${ }^{-1}$ in Bottle gourd, while their interaction was found nonsignificant.

Among the different Bottle gourd varieties, more fruits vine ${ }^{-1}(7.75)$ were observed in Lauki followed by CO1 hybrid (6.95), while lowest fruits vine $^{-1}$ (6.25) were recorded in Pusa samridhi.

In case of pinching treatment, more fruits vine $^{-1}$ was observed in plants pinched at $3^{\text {rd }}$ node stage (7.77) followed by pinching at $2^{\text {nd }}$ node (7.33), while lowest fruits vine ${ }^{-1}$ (6.16) were noted in plants that were not pinched.

The increase in number of fruits vine ${ }^{-1}$ might in pinched plants is due to the activation of endogenous hormones, which accelerates the growth phases and balance the carbon nitrogen ratio that enhances female flowers production [24]. The lateral branches bear more female flowers; 
therefore, more number of fruits occurs on lateral vines [15]. Pimpini and Gianquinto [19] demonstrated that pinching is beneficial for good source-sink relationship which enhances number of female flowers production and fruits set, moreover increased number of fruits due to the diversion of photo assimilates towards lateral branches. Similar to our results pinching was effective treatment to enhance number of fruits in different vegetables i.e. Cucumber Pimpini $\mathrm{F}$ and Gianquinto Fenugreek [28].

\section{Average fruit weight (g)}

In (Table 2), the mean values for average fruit weight is calculated. As evident from the ANOVA table that pinching practice and varieties significantly influence average fruit weight in Bottle gourd while their interaction was found non-significant. Among the tested Bottle gourd varieties, highest average fruit weight $(418.50 \mathrm{~g})$ were observed in CO1 hybrid followed by Pusa samridhi $(415.75 \mathrm{~g})$, while lowest average fruit weight $(399.17 \mathrm{~g})$ were recorded in variety Lauki.

In case of pinching practice, plants that pinched at $3^{\text {rd }}$ node stage produced highest average fruit weight $(419 \mathrm{~g})$ followed by pinching at $2^{\text {nd }}$ node (416 g), while lowest average fruit weight $(400.33 \mathrm{~g})$ were recorded for plants that were not pinched.

The increase in average fruit weight might be due to the better source-sink relationship, pinching treatment balance carbon and nitrogen ratio in the plant, and also enhance photosyanthate movement towards sink thus improve fruit weight [29]. Buczkowska [30] demonstrated that pinching is effective practice to increase fruit diameter and thus increases fruit weight. Similar to our findings more average fruit weight with pinching practice has been documented in other vegetables i.e. Fenugreek [31], Okra [32] and Cucumber [17].

\section{Total yield plant ${ }^{-1}$}

In (Table 2), the mean values for total yield plant $^{-1}$ is calculated. As evident from the ANOVA table that pinching practice and varieties significantly influence total yield plant $^{-1}$ in Bottle gourd while their interaction was found non-significant.

Among the different Bottle gourd varieties, highest total yield plant ${ }^{-1}(5.04 \mathrm{~kg})$ was observed in $\mathrm{CO} 1$ hybrid followed by Lauki $(4.58 \mathrm{~kg})$, while lowest total yield plant ${ }^{1}(4.48 \mathrm{~kg})$ were noted for Pusa samridhi.

In case of pinching, highest yield plant ${ }^{-}$ ${ }^{1}(5.44 \mathrm{~kg})$ was observed in plants pinched at $3^{\text {rd }}$ node stage followed by $2^{\text {nd }}$ node stage $(5.03 \mathrm{~kg})$, while lowest total yield plant $^{-1}$ $(3.96 \mathrm{~kg})$ were noted for plants that were not pinched.

In pinched plant the photosynthate diverts to lateral branches, thus increasing female flowers production and produce more fruits [13]. Anand et al. [14] demonstrated that due to pinching treatment plants become physiologically active and the concentration of photosynthate diverts to lower parts of the plant that results suppresses growth of the main stem while lateral branches increases in number. The lateral branches have more carbohydrates as compared to main stem, therefore they bear more female flowers and hence more fruits set occur [15]. Similarly, to the findings of this study, pinching at $3^{\text {rd }}$ node stage was beneficial for getting maximum yield in Butter nut [15], Tomatoes [16] and Cucumber [17].

\section{Total yield ha-1 (Tonns)}

In (Table 2), the mean values for total yield $\mathrm{ha}^{-1}$ is calculated. As evident from the ANOVA table that pinching practice and varieties significantly influence total yield hectare $^{-1}$ in Bottle gourd while their interaction was found non-significant.

Among the different Bottle gourd varieties, highest total yield hectare ${ }^{-1}$ was observed for CO1 hybrid (12.7 t) followed by Lauki $(12.2 \mathrm{t})$. while lowest total yield $\mathrm{ha}^{-1}(11.05$ t) was noted for Pusa samridhi.

In case of pinching, highest total yield $\operatorname{hectare}^{-1}(12.9 \mathrm{t})$ was observed in plants pinched at $3^{\text {rd }}$ node stage followed by pinching treatment at $2^{\text {nd }}$ node stage (12.7 t), while lowest total yield hectare ${ }^{-1}$ (11.02 
t) were noted for plants that were not pinched.

Due to pinching treatment, the diversion of photo assimilates to lateral branches take place [15]. Lateral branches have more carbohydrates as compared to main stem, therefore they bear more female flowers, and hence more fruit set occurred, thus increasing the yield ha- ${ }^{-1}$ [14]. Patel et al. [13] demonstrated that due to pinching practice, plants produce more female flowers and hence increases the fruit yield. Similar to the findings of our study, more yield hectare ${ }^{-1}$ have been recorded in, Fenugreek [20], Tomatoes [16] and Cucumber [17] with pinching treatments.

Table 2. Fruit set (\%age), Length of fruit $(\mathrm{cm})$, Number of fruits vine ${ }^{-1}$, Average fruit weight (g), Total yield plant ${ }^{-1}(\mathrm{~kg})$, Total yield ha ${ }^{-1}$ (ton)

\begin{tabular}{|c|c|c|c|c|c|c|}
\hline Factor Levels & $\begin{array}{c}\text { Fruit } \\
\text { set } \\
(\% \text { age })\end{array}$ & $\begin{array}{l}\text { Length of } \\
\text { fruit }(\mathrm{cm})\end{array}$ & $\begin{array}{l}\text { Number of } \\
\text { fruits vine }^{-1}\end{array}$ & $\begin{array}{l}\text { Average } \\
\text { fruit } \\
\text { weight (g) }\end{array}$ & $\begin{array}{c}\text { Total } \\
\text { yield } \\
\text { plant }^{-1} \\
(\mathbf{k g})\end{array}$ & $\begin{array}{l}\text { Total } \\
\text { yield ha }^{-1} \\
\text { (ton) }\end{array}$ \\
\hline \multicolumn{7}{|c|}{ Pinching stages } \\
\hline No Pinching & 74.47 & $21.83 \mathrm{~b}$ & $6.16 \mathrm{~B}$ & $400.33 \mathrm{~b}$ & $3.96 \mathrm{D}$ & $11.02 \mathrm{~B}$ \\
\hline $1^{\text {st }}$ node & 69.75 & $22.80 \mathrm{ab}$ & $6.67 \mathrm{AB}$ & $409.11 \mathrm{ab}$ & $4.37 \mathrm{C}$ & $11.28 \mathrm{~B}$ \\
\hline $2^{\text {nd }}$ node & 66.64 & $23.94 \mathrm{a}$ & $7.33 \mathrm{AB}$ & $416.00 \mathrm{a}$ & $5.03 \mathrm{~B}$ & $12.74 \mathrm{~A}$ \\
\hline $3^{\text {rd }}$ node & 70.00 & $24.33 \mathrm{a}$ & $7.78 \mathrm{~A}$ & $419.11 \mathrm{a}$ & $5.44 \mathrm{~A}$ & $12.92 \mathrm{~A}$ \\
\hline $\operatorname{LSD}(\mathbf{P} \leq 0.05)$ & 13.04 & 1.89 & 1.20 & 13.22 & 0.31 & 0.90 \\
\hline \multicolumn{7}{|c|}{ Varieties } \\
\hline Lauki & 65.30 & $23.00 \mathrm{~b}$ & $7.75 \mathrm{a}$ & $399.17 \mathrm{~b}$ & $4.58 \mathrm{~B}$ & $12.21 \mathrm{~A}$ \\
\hline Pusa Samridhi & 70.00 & $24.45 \mathrm{a}$ & $6.25 \mathrm{~b}$ & $425.75 \mathrm{a}$ & $4.48 \mathrm{~B}$ & $11.05 \mathrm{~B}$ \\
\hline C01 Hybrid & 75.33 & $22.25 \mathrm{~b}$ & $6.95 \mathrm{ab}$ & $418.50 \mathrm{a}$ & $5.04 \mathrm{~A}$ & $12.71 \mathrm{~A}$ \\
\hline $\operatorname{LSD}(P \leq 0.05)$ & 13.07 & 1.32 & 0.80 & 15.50 & 0.44 & 1.08 \\
\hline
\end{tabular}

\section{Conclusion and Recommendations}

The research study "Influence of Pinching on growth and yield of Bottle gourd (Lagenaria siceraria L.) was conducted during April-October 2019 at the Palatto research Farm of AMK campus Mardan, The University of Agriculture Peshawar. The study was carried out according to RCBD design with split plot arrangement. Bottle gourd varieties were assigned to main plot while pinching levels were assigned to sub plot. Factor 'A' (varieties) had three levels i.e. Lauki, Pusa samridhi and $\mathrm{CO} 1$ hybrid and Factor 'B' (pinching) have four levels i.e. No pinching, pinching treatment at $1^{\text {st }}$ node stage, $2^{\text {nd }}$ node stage and $3^{\text {rd }}$ node stage. Three bottle gourd varieties were studied under four pinching levels and the experiment was replicated thrice.

According to data obtained in these experiments, pinching treatment significantly affected the growth and yield parameters of bottle gourd. Pinching treatment at $3^{\text {rd }}$ node stage significantly produced more number of lateral branches (3.55), early male flower appearance ( 36.33 days), early female flower appearance (41.33 days),, more female flowers vine ${ }^{-1}$ (9.11), highest length of fruit $(24.33 \mathrm{~cm})$, lowest vine length $(2.36 \mathrm{~m})$, more fruits vine $^{-1}$ (7.78), maximum average fruit weight (419.11g), highest total yield plant ${ }^{-1}$ $(5.44 \mathrm{~kg})$ and maximum yield $\mathrm{ha}^{-1}(12.92$ t), while more male flower vine ${ }^{-1}$ (70.11) were recorded for un-pinched plants. Furthermore, among the tested varieties CO1 hybrid produced more number of lateral branches plant ${ }^{-1}$ (3.28), early male flower appearance (35.50 days), early female flower appearance (40.25 days), lowest vine length $(2.39 \mathrm{~m})$, highest fruit weight (418 g), highest yield plant ${ }^{-1}$ (5.04 $\mathrm{kg}$ ) and highest yield ha-1 (12.71 t). On the other hand highest length of fruit (24.45 $\mathrm{cm}$ ) was recorded for variety Pusa samridhi, while more number of male flowers vine ${ }^{-1}$ (68), more Nos. of female flowers vine ${ }^{-1}$ 
(9.16) and fruits vine ${ }^{-1}(7.75)$ were noted for Lauki.

The following findings can be concluded from the results of the current experiments.

- Pinching practice at $3^{\text {rd }}$ node significantly increased number of lateral branches, earliness in male flower appearance, earliness in female flower appearance, lowest vine length, more female flowers $v^{\text {vine }}{ }^{-1}$, lengthy fruit, more number of fruits vine ${ }^{-1}$, fruit weight, and yield of Bottle gourd varieties.

- Among the tested Bottle gourd varieties, CO1 hybrid produced more number of lateral branches, earliness in male flower appearance, earliness in female flower appearance, lowest vine length, highest fruit weight, and total yield ha ${ }^{-1}$ of Bottle gourd.

- The varieties of CO1 hybrid and Lauki were at par in total yield ha ${ }^{-1}$ of Bottle gourd.

- There was no interactive effect found between pinching and varieties of Bottle gourd.

On the basis of the findings of the current study the subsequent recommendation can be made.

Bottle gourd varieties Lauki and CO1 hybrid are better in term of yield whereas pinching at $3^{\text {rd }}$ node stage is good practice for getting better growth and yield of bottle gourd.

\section{Authors' contributions}

Experiment conceived and designed by: $\mathrm{M}$ Naafe, G Nabi \& M Irshad, Performed the experiment by: $M$ Naafe \& $M$ Irshad, Analysed the data by: S Ali \& MN Khan, Contributed reagents/ materials/ analysis tools; M Naafe \& R Hayat, Wrote the paper by: M Naafe \& M Irshad.

\section{References}

1. Robinson RW \& Decker-Walters DS (1997). Cucurbits (Crop Production Science in Horticulture no. 6). New York: Cab International

2. Chung HD, Choi YJ \& Shin SH (1999). Morphological Characteristics and Germination of the Korean Native Bottle gourd (Lagenaria siceraria Standl.) Seeds. $J$.
3. Parle M \& Kaur S (2011). Is bottle gourd a natural guard. Int Res J Pharm 2(6):13-17.

4. Singh N \& Kalda TS (2000). Textbook of vegetables, tuber crops and spices (Eds. S. 252 Thamburaj and N. Singh). ICAR, New Delhi 2000(1): 271-278

5. Sidhu ABS, Verdier-Pinard D \& Fidock DA (2002). Chloroquine resistance in Plasmodium falciparum malaria parasites conferred by pfcrt mutations. Int J Horti Sci 298(1): 210-213.

6. Huyskens PL (1992). Mobile and static molecular disorder in liquids. J Molecu Sci 274(1): 223-246.

7. Tan YC, Lai JS, Adhikari KR, Shakya SM, Shukla AK \& Sharma KR (2009). Efficacy of mulching, irrigation and nitrogen applications on bottle gourd and okra for yield improvement and crop diversification. Irri Drainage Sys23(1): 2541.

8. Jan ND, Iqbal M, Ghafoor A, Waseem K \& Jillani MS (2000). Effect of NPK fertilizers and spacing on the yield of bottle gourd (Lagenaria siceratia M). Pak J Biol Sci 20(1):165-170

9. Ghosh MS \& Bose TK (1970). Sex modification in cucurbitaceous plants by using CCC. P Bue Aires 27(1): 131-135.

10. Haque MM, Hasanuzzaman M \& Rahman ML (2009). Effect of light intensity on the morpho-physiology and yield of bottle gourd (Lagenaria vulgaris). Acad J Plant Sci 2(3): 158-161.

11. Singh SP, Maurya IB \& Singh NK (1996). Occurrence of andromonoecious form in bottle gourd, (Lagenaria siceraria) exhibiting monogenic recessive inheritance. J Curr Sci 70(6): 458-459.

12. Fruit, vegetable and condiments statistics of Pakistan (2015-2016). Govt. Of Pakistan, Ministry of Food security and Research (Economic Wing), Islamabad, Pakistan.pp.111.

13. Patel AN, Parmar VK, Nayak SR \& Patel NM (2017). Influence of pinching and plant growth regulators on morphological and sex expression of bottle gourd (Lagenaria siceraria L.). Int J Chem Sci 5(4): 20352038.

14. Anand M, Rohini N \& Sadasakthi A (2014). Influence of training and pinching on growth, flowering and physiological characters in bottle gourd cv. CBgH1. Trends in Biosci 7(17): 2524-2527. 
15. Eve B, Tuarira M, Moses M \& Thomas M (2016). The influence of pinching on the growth, flowering pattern and yield of butternuts (Cucurbita moschata). Int $J$ Horti Orn Plants 16(2): 019-026.

16. Tswanya NM \& Olaniyi OJ (2016). Effects of pinching time on growth and fruit yield of three tomato varieties (Lycopersicon lycopersicum Mill) in the southern guinea savanna zone of nigeria. Int J Agri 1(1): 3040.

17. Patel SM, Tandel MB, Desai MK, Pathak JG, Behera LK \& Parmar MR (2018). Economics of cucurbitaceous vegetable crops under teak (Tectona grandis $\mathrm{Lf}$ ) based silvi-horticultural system in South Gujarat. Int JCS 6(2): 119-123.

18. Steel RG \& Torrie JH (1986). Principals and procedures of statistics. A biometrical approach, McGraw-Hill (2nd Edition) Book Company, New Yor

19. Pimpini F \& Gianquinto G (1992), October. Influence of pinching, crop density and different growing methods on fresh market tomatoes grown under protected cultivation for early production. In III International Symposium on Protected Cultivation in Mild Winter Climates 357: 343-352.

20. Krishanveni V, Padmalatha T, Padma SS \& Parsad ALN (2014). Effect of Pinching and plant growth regulators on growth and flowering in fenugreek (Trigonella foenumgraecum L.), J Plant Arch 14(2): 901-907.

21. Sudarshan JS (2004). Influence of apical bud pinching, chemical spray and physiological maturity on seed yield and quality of fenugreek. An M. Sc. thesis, University of Agricultural Sciences, Dharwad, India 4: 73-78.

22. Nayak SR, Parmar VK, Patel AN, Smita L \& Tandel YN (2018). Efficacy of pinching and plant growth regulators in enhancing yield characters of cucumber (Cucumis sativus L.). Int JCS 6(1): 1804-1807.

23. Gosselin A \& Guillaume G (1990). The influence of pruning and season on fruit development in a crop of cucumber. Canadian. J Plant Sci 69(3): 1037-1048.

24. Higashide T, Gotoh I, Suzuki K, Yasuba K, Tsukazawa K, Ahn D \& Iwasaki Y (2012). Effects of pinching and lowering on cucumber yield and yield components. $J$ Horti Res Japan 11(4): 523-529.

25. Lakshmi J, Gowda R, Narayanaswamy S \& Shivanandam VN (2014). Influence of preflowering pinching and Maleic hydrazide spray on plant growth, seed yield and quality attributes in fenugreek. Int $J$ Legume Res 38(3): 353-357.

26. Riley KW (1998). International collaboration in plant genetic resource: The role of IBPGR on plant germplasm conservation: Proc of Int Symp Held at Taiwan Agric Res Institute 98: 111-122

27. Frimpong $\mathbf{J}$ (2011). Effect of fertilizer type and nodal pinching on growth, flowering pattern and yield of cucumber (Cucumis sativus) (Doctoral dissertation).

28. Kauser H, Bhoomika HR \& Ibaad MH (2018). Interaction Effects of Different Sowing Dates and Stage of Pinching on Growth, Yield and Economics of Fenugreek (Trigonella foenum-graecum L.). Int J Pure Appl Biol Sci 6(2): 167-171.

29. Singh B, Mangal JL \& Pandita ML (1982). Effect of pruning, spacing and fertilizer levels on flowering, fruiting, yield and quality of muskmelon. J Res Har Agri Uni 82(1): 55-59

30. Buczkowska H (2001). The effect of seedling pinching on yields and quality of chilli pepper. J Veg Crops Res Bull 55: 7780.

31. Bairagi S (2016). Effect of pinching of apical buds and chemical sprays on yield and quality of fenugreek seed. Ann of Hort 9(2): 177-181.

32. Abed AH (2016). Influence of whey foliar spraying and growing point pinching on growth and yield parameters of okra. Iraqi J Agri Sci 47(4). 